\title{
Mid-depth South Atlantic Ocean circulation and chemical stratification during MIS-10 to 12: implications for atmospheric $\mathrm{CO}_{2}$
}

\author{
A. J. Dickson ${ }^{1}$, M. J. Leng ${ }^{2,3}$, and M. A. Maslin ${ }^{1}$ \\ ${ }^{1}$ Environmental Change Research Centre, Department of Geography, University College London, Pearson Building, \\ Gower Street, London, WC1E 6BT, UK \\ ${ }^{2}$ NERC Isotope Geosciences Laboratory, British Geological Survey, Keyworth, Nottingham, NG12 5GG, UK \\ ${ }^{3}$ School of Geography, University of Nottingham, Nottingham, NG7 2RD, UK
}

Received: 13 May 2008 - Published in Clim. Past Discuss.: 5 June 2008

Revised: 20 October 2008 - Accepted: 20 October 2008 - Published: 6 December 2008

\begin{abstract}
A detailed record of benthic foraminifera carbon isotopes from the intermediate-depth South East Atlantic margin shows little glacial-interglacial variability between MIS-12 to MIS-10, suggesting that Northern Atlantic deepwaters consistently penetrated to at least $30^{\circ} \mathrm{S}$. Millennialscale increases in either the mass or flux of northern-sourced deepwaters over the core site occurred alongside reductions in Lower North Atlantic Deep Water recorded in North Atlantic sediment cores and show that the lower and intermediate limb of the Atlantic deepwater convective cell oscillated in anti-phase during previous glacial periods. In addition, a $500 \mathrm{yr}$ resolution record of the Cape Basin intermediate-deep $\delta^{13} \mathrm{C}$ gradient shows that a reduction in deep Southern Ocean ventilation at the end of MIS-11 was consistent with a modelled $\mathrm{CO}_{2}$ drawdown of $\sim 21-30 \mathrm{ppm}$. Further increases in the Southern Ocean chemical divide during the transition into MIS-10 were completed before minimum $\mathrm{CO}_{2}$ levels were reached, suggesting that other mechanisms such as alkalinity changes were responsible for the remaining $\sim 45 \mathrm{ppm}$ drawdown.
\end{abstract}

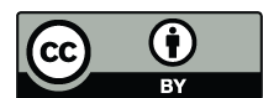

Correspondence to: A. J. Dickson (a.j.dickson@dunelm.org.uk)

\section{Introduction}

A number of mechanisms within the earth-ocean-atmosphere system have the potential to exert a positive or negative feedback on orbitally forced climate variability. Changes in ocean circulation can have an impact on climate changes over timescales ranging from decades to millennia, by altering the distribution of alkalinity in the oceans, and thus changing atmospheric $\mathrm{CO}_{2}$ (e.g. Boyle, 1988; Toggweiler et al., 1999; Sigman and Boyle, 2000), or by changing the distribution of surface heat transported by ocean currents (Clark et al., 2002). Glacial-interglacial changes in ocean circulation have been reconstructed in a number of studies, traditionally using changes in the carbon isotope ratios of benthic foraminifera (e.g. Curry and Lohmann, 1983; Shackleton et al., 1983; Boyle and Keigwin, 1985, 1986; Boyle and Keigwin, 1987; Oppo and Fairbanks, 1987; Curry et al., 1988; Duplessy et al., 1988; Oppo et al., 1990; Raymo et al., 1990; Charles et al., 1996; Yu et al., 1996; Lynch-Stieglitz et al., 2007; Martinez-Mendez et al., 2008) and have consistently shown that the production of Lower North Atlantic Deep Water (LNADW) decreased during the cold climates of the Last Glacial Maximum (LGM) and during Heinrich events and was replaced by southern sourced deepwaters that expanded into the Northern Atlantic below $\sim 2000 \mathrm{~m}$. At the same time, Glacial North Atlantic Intermediate Water (GNAIW) spread southwards at depths shallower than $2000 \mathrm{~m}$ to at least $30^{\circ} \mathrm{S}$ (Duplessy et al., 1988; Oppo and Lehman, 1993; Oppo and Horowitz, 2000; Curry and Oppo, 2006). 


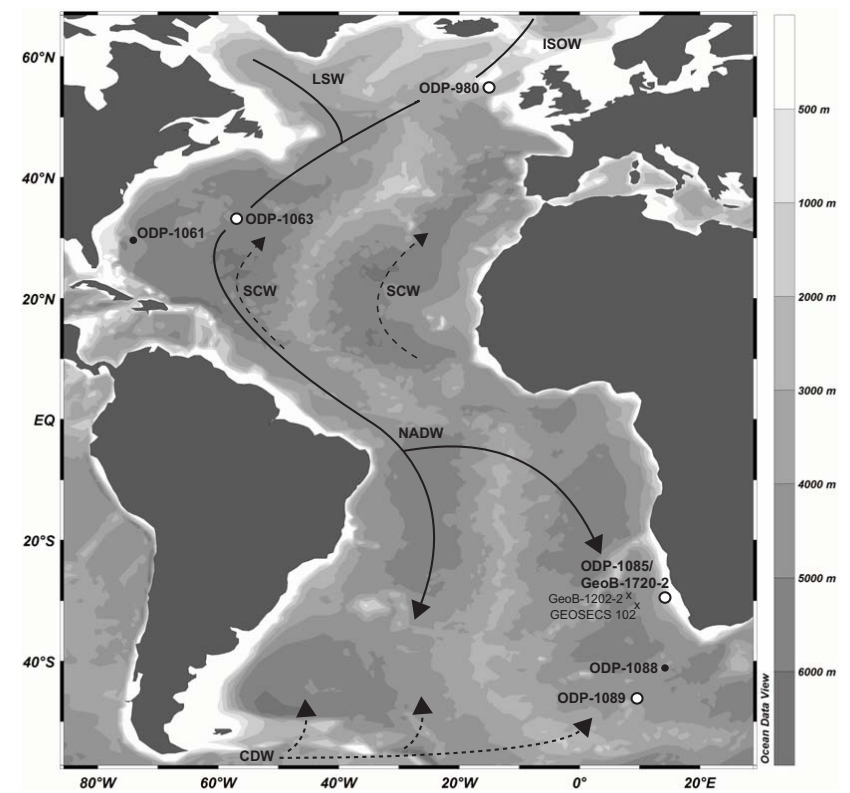

Fig. 1. Locations of tuned benthic $\delta^{13} \mathrm{C}$ records (open circles) and other core sites mentioned in the text (filled circles), created using Ocean Data View (Schlitzer, 2006). The locations of geochemical profiles shown in Fig. 2 are plotted as crosses. Arrows indicate synoptic deep-water flow paths of North Atlantic Deep Water (NADW), Circumpolar Deep Water (CDW, dashed line) and Southern Component Water (SCW, dashed line, comprising CDW and Antarctic Bottom Water) through the North and South Atlantic basins. It should be noted that NADW intersects CDW into an upper and lower component east of Drake Passage.

Marine Isotope Stage (MIS) 11, the most recent interglacial period to occur under a similar pattern of orbital forcing to the Holocene (Loutre and Berger, 2003) has the potential to provide information on the type and magnitude of climate variability that could be expected under "baseline" (i.e. non-anthropogenic) conditions. However, few detailed records of deepwater variability during the middle Brunhes period have been produced, and those that do exist are predominantly located in the North Atlantic Ocean (e.g. Oppo et al., 1998; Poli et al., 2000; Thunell et al., 2002; McManus et al., 2003; Hall and Becker, 2007; Martrat et al., 2007).

Here we present a new $\sim 450 \mathrm{yr}$ resolution benthic foraminifera $\delta^{13} \mathrm{C}$ record from ODP Site-1085 in the South Eastern Atlantic Ocean $\left(29.2^{\circ} \mathrm{S}, 13.6^{\circ} \mathrm{E}, 1713 \mathrm{~m}\right.$ depth, Fig. 1) that extends between $480-330 \mathrm{ka}$. The data show that the increased advection of GNAIW to intermediate depths in the South East Atlantic Ocean at millennial-timescales was coincident with a reduced production of LNADW, possibly in response to the delivery of meltwater to sites of deepwater production in the North Atlantic. Furthermore, similarities between the structure of the Cape Basin vertical

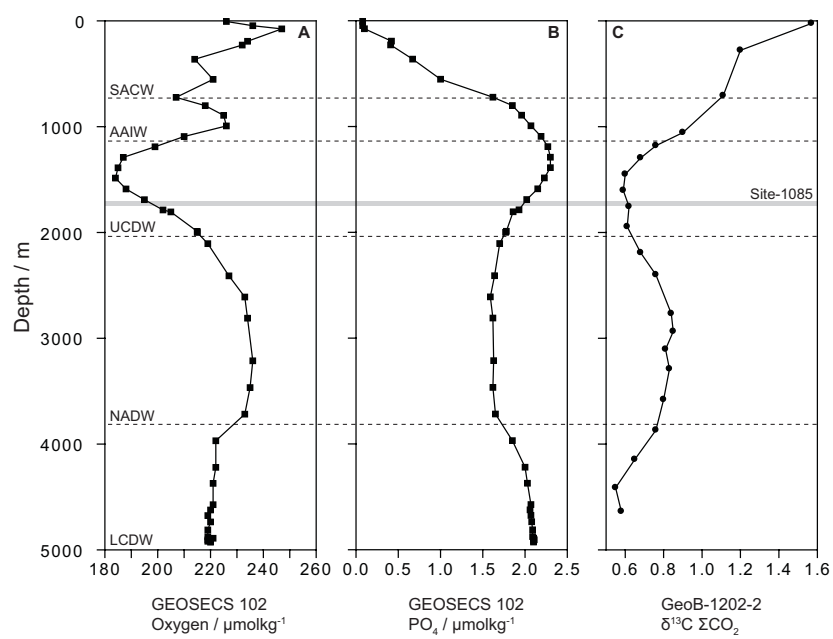

Fig. 2. Dissolved oxygen, phosphate, and $\delta^{13} \mathrm{C} \Sigma \mathrm{CO}_{2}$ profiles from GEOSECS 102 and GeoB-1202 (Bickert and Wefer, 1999), with delineations of the main deep water masses in the Cape Basin. The depth of studied core ODP Site-1085 is marked with a shaded horizontal band.

$\delta^{13} \mathrm{C}$ gradient and the spliced EPICA Dome C (EDC)/Vostok atmospheric $\mathrm{CO}_{2}$ record supports previous suggestions of a close link between ventilation of the deep ocean and changes in atmospheric greenhouse gas concentrations.

\section{Modern deepwater hydrography at Site-1085}

The structure of the South Atlantic water column has been discussed in detail by McCartney (1977), Saunders and King (1994), and Siedler et al. (1996), and is shown in Fig. 2 with profiles of dissolved oxygen, phosphate and $\delta^{13} \mathrm{C} \Sigma \mathrm{CO}_{2}$ from GEOSECS Station 102 (Kroopnick, 1980). NADW flows southwards in the Western Atlantic between $1200-4000 \mathrm{~m}$, and is marked by dissolved $\mathrm{O}_{2}$ concentrations of $\sim 230 \mu \mathrm{mol} \mathrm{kg}^{-1}$ and $\mathrm{PO}_{4}$ concentrations of $\sim 1.6 \mu \mathrm{mol} \mathrm{kg}^{-1}$. South of the Equator, this flow branches into two components and enters the South East Atlantic, where it can be identified between $2000-3500 \mathrm{~m}$ (Fig. 2a and b). Northwards-flowing Circumpolar Deep Water (CDW) is intersected by NADW east of Drake Passage, and bifurcates into an upper (UCDW) and lower (LCDW) branch. UCDW can be identified by low dissolved oxygen $\left(<200 \mu \mathrm{mol} \mathrm{kg}^{-1}\right)$ and high phosphate $\left(\sim 2 \mu \mathrm{mol} \mathrm{kg}{ }^{-1}\right)$ concentrations, which are derived from its origins in Indian and Pacific waters (Whitworth and Nowlin Jr., 1987). These properties are modified slightly by mixing with underlying NADW and are identifiable in the GEOSECS 102 data between $\sim 1100 \mathrm{~m}$ and $2000 \mathrm{~m}$. LCDW occupies the bottom of the Cape Basin below $3500 \mathrm{~m}$ (Siedler et al., 1996) where it can be distinguished from NADW by comparatively higher phosphate and 
lower oxygen concentrations. Antarctic Intermediate Water (AAIW) is formed by the subduction of upwelled CDW at the sub-Antarctic front (McCartney, 1977), and fills much of the South Atlantic at depths between 700-1000 m.

Modern $\delta^{13} \mathrm{C} \Sigma C O_{2}$ profiles in the southeastern Atlantic are clearly related to the distribution of these water masses (Kroopnick, 1980; Bickert and Wefer, 1999). In Fig. 2c, NADW is clearly distinguished by high $\delta^{13} \mathrm{C}$ values of $+0.8 \%$, while values for AAIW, UCDW and LCDW are $<+0.5 \%$. Site- 1085 is currently located within the NADW/UCDW mixing boundary, where T-S data suggests that it is influenced by a respective 60/40 mixture of each water mass.

\section{Methods}

Benthic foraminifera samples from Site-1085 were picked from the $>250 \mu \mathrm{m}$ fraction at $2 \mathrm{~cm}$ intervals between 11.00 $17.50 \mathrm{mbsf}$. Measurements were performed on 2-6 individuals of the epibenthic species Cibicidoides wuellerstorfi and the infaunal species Uvigerina spp. where $C$. wuellerstorfi was absent. Each sample was gently crushed and homogenised and aliquots were reacted at $90^{\circ} \mathrm{C}$ in a VG IsoCarb common acid bath system attached to an Optima mass spectrometer. $\delta^{18} \mathrm{O}$ and $\delta^{13} \mathrm{C}$ values are expressed relative to the Vienna PDB scale by reference to an internal laboratory working standard (KCM) calibrated against NBS-19. Internal precision was monitored with repeat measurements of KCM and was $0.09 \%$ of $\delta^{18} \mathrm{O}$ and $0.06 \%$ for $\delta^{13} \mathrm{C}$ over the period of analysis. Intra-sample variability was assessed from a series of repeat measurements made on several samples. $\delta^{18} \mathrm{O}$ values of $C$. wuellerstorfi have been corrected by $+0.64 \%$ and $\delta^{13} \mathrm{C}$ values of Uvigerina spp. have been corrected by $+0.90 \%$ o to correct for offset from isotopic equilibrium (Duplessy et al., 1984).

Foraminifera fragments $>150 \mu \mathrm{m}$ have also been counted as a qualitative measure of carbonate dissolution (e.g. Le and Shackleton, 1992). In order to account for changes in the abundance of foraminifera through time, the abundance of fragments is expressed relative to the mass of sandsized material $(>63 \mu \mathrm{m})$, which is dominated by planktonic foraminifera. An age-model for Site-1085 has been generated through visual correlation to the LR04 benthic oxygen isotope stack (Lisiecki and Raymo, 2005). This approach yields a study section extending between $330-480 \mathrm{ka}$, at an average temporal resolution of $450 \mathrm{yr}$.

\section{Results}

Repeat measurements of several C. wuellerstorfi samples gave an estimate of intra-sample variance of $\pm 0.15 \%$ o for $\delta^{18} \mathrm{O}$ and $\pm 0.12 \%_{\text {o for }} \delta^{13} \mathrm{C}$ (Table 1 ). Fewer repeat measurements for Uvigerina spp. gave an estimate of $\pm 0.07 \%$ o for $\delta^{18} \mathrm{O}$ and $\pm 0.09 \%$ ofor $\delta^{13} \mathrm{C}$. The C. wuellerstorfi/Uvigerina
Table 1. Repeated C. wuellerstorfi isotopic measurements.

\begin{tabular}{llllll}
\hline Sample & $\mathrm{n}$ & $\begin{array}{l}\text { Mean } \\
\delta^{18} \mathrm{O} / \mathrm{VPDB}\end{array}$ & $1 \sigma \delta^{18} \mathrm{O}$ & $\begin{array}{l}\text { Mean } \\
\delta^{13} \mathrm{C} / \mathrm{VPDB}\end{array}$ & $1 \sigma \delta^{13} \mathrm{C}$ \\
\hline 3W-51CW & 2 & +4.10 & 0.15 & +0.26 & 0.03 \\
4W-38CWR & 3 & +3.53 & 0.32 & +0.33 & 0.14 \\
4W-50CWR & 3 & +3.52 & 0.41 & +0.29 & 0.33 \\
4W-86CWR & 3 & +3.62 & 0.05 & +0.56 & 0.05 \\
4W-106CW & 2 & +3.32 & 0.00 & +0.24 & 0.12 \\
4W-108CWR & 3 & +3.23 & 0.11 & +0.33 & 0.10 \\
4W-128CW & 4 & +3.76 & 0.06 & +0.49 & 0.18 \\
4W-146CWR & 3 & +3.30 & 0.08 & +0.61 & 0.06 \\
5W-31CWR & 3 & +2.91 & 0.20 & +0.81 & 0.10 \\
1 $\sigma$ average & - & - & 0.15 & - & 0.12 \\
\hline
\end{tabular}

spp. $\delta^{18} \mathrm{O} / \delta^{13} \mathrm{C}$ data from Site-1085 are shown in Fig. 3, along with foraminifera fragment abundances and accumulation rates. The $\delta^{18} \mathrm{O}$ record shows the most obvious features of MIS-11, in particular the long deglaciation during termination 5 and a decrease in the rate of $\delta^{18} \mathrm{O}$ change in the early part of the interglacial from $\sim 424 \mathrm{ka}$. Along with several $\delta^{18} \mathrm{O}$ minima during MIS-12 and late MIS-10, these features permitted the transfer of the LR04 chronology to the studied section of Site-1085. $\delta^{13} \mathrm{C}$ values of individual data points range from 0 to $+1 \%$. However, the average glacial-interglacial change in $\delta^{13} \mathrm{C}$ is close to the mean-ocean changes found for the last deglaciation (Curry et al., 1988; Duplessy et al., 1988, see discussion below). Several short-term $\delta^{13} \mathrm{C}$ increases are superimposed on this longterm trend. These increases are defined as periods when $\delta^{13} \mathrm{C}$ values rise by +0.1 to $+0.3 \%$, and are maintained for several adjacent data points before decreasing again to pre-excursion values (shaded bands in Fig. 3). Foraminifera fragments indicate varying levels of carbonate preservation through the study interval. Highest abundances/accumulation rates occur at the beginning of MIS-12, during the climate optimum of MIS-11 (424-390 ka), towards the end of MIS-11 (383$370 \mathrm{ka})$ and during MIS-10 (355-345 ka). The intervening intervals are characterised by relatively low amounts of fragmentation.

\section{Discussion}

5.1 Effects of organic matter flux and air-sea carbon exchange on benthic foraminifera $\delta^{13} \mathrm{C}$ in Site-1085

The release of ${ }^{12} \mathrm{C}$ into bottom waters during organic matter breakdown may cause locally lowered $\delta^{13} \mathrm{C}$ values in benthic foraminifera. Although $C$. wuellerstorfi has been demonstrated to calcify close to bottom-water carbon isotopic equilibrium (Graham et al., 1981; Belanger et al., 1981; Duplessy et al., 1984), a highly seasonal flux of organic matter to the seafloor can generate $C$. wuellerstorfi blooms whose $\delta^{13} \mathrm{C}$ is 


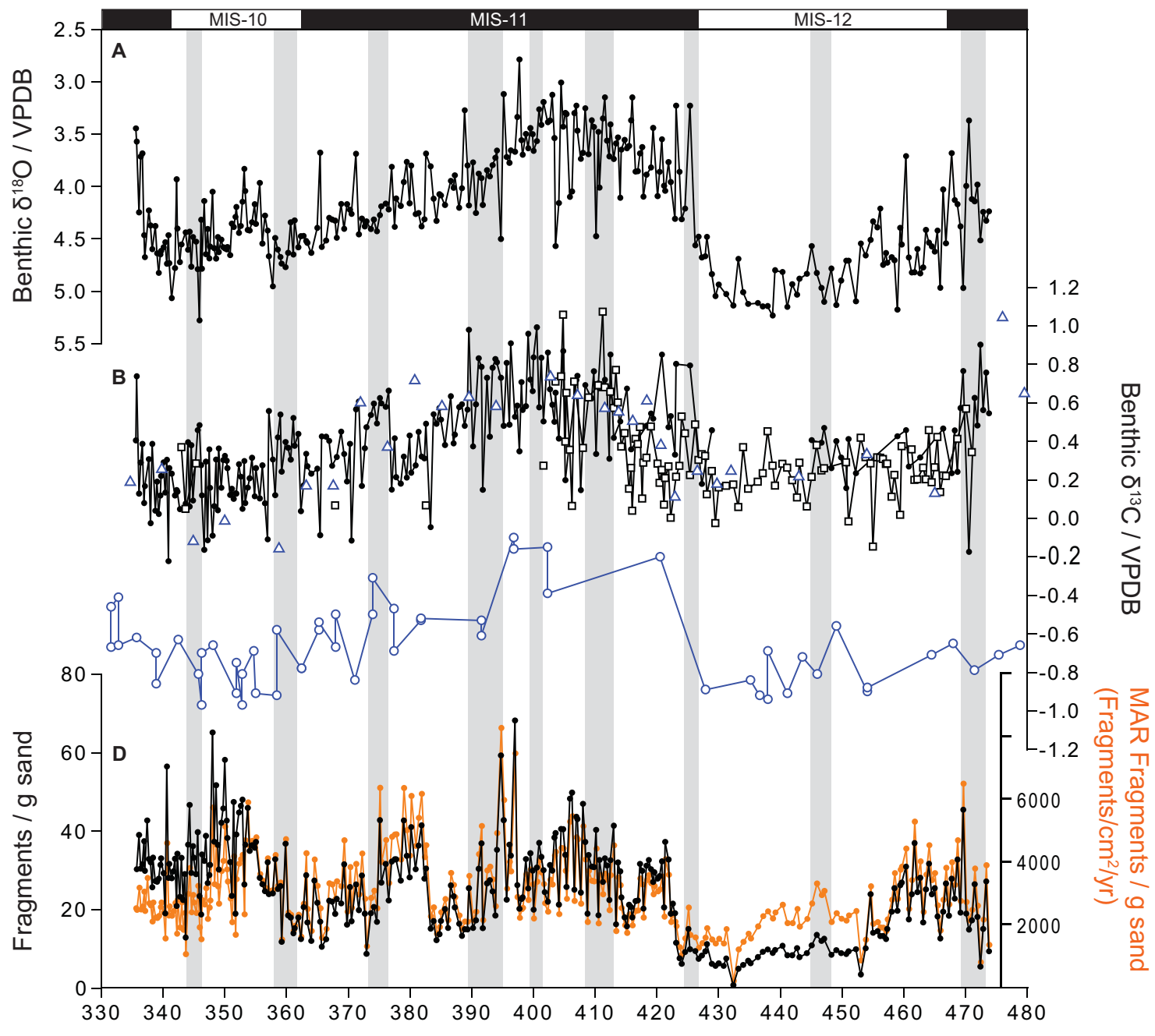

LR04 age / ka

Fig. 3. Benthic isotope and foraminifera fragment data from Site-1085. (a) Benthic $\delta^{18} \mathrm{O}$ data composed of C. wuellerstorfi and Uvigerina spp. data, the latter corrected by $+0.64 \% \%^{\circ}$ (b) $\delta^{13} \mathrm{C}$ data composed of $C$. wuellerstorfi (circles) and Uvigerina spp. corrected by $+0.9 \%$ (open squares). Benthic $\delta^{13} \mathrm{C}$ data from Site-849 ( $-0.5 \%$ o for clarity) and Site-1088 are plotted on their original timescales as blue open circles and open triangle, respectively. (c) Abundance (black) and mass accumulation rate (orange) of foraminifera fragments per gram sand $>150 \mu \mathrm{m}$. Shaded vertical bands represent millennial-scale increases in Site-1085 benthic $\delta^{13} \mathrm{C}$.

offset from bottom water $\Sigma \mathrm{CO}_{2}$ by -0.4 to $-0.6 \%$ (Mackensen et al., 1993; Bickert and Wefer, 1999). A number of lines of evidence suggest that this "phytodetritus" effect does not unreasonably compromise the $C$. wuellerstorfi $\delta^{13} \mathrm{C}$ data from Site-1085. Firstly, highly pulsed seasonal organic matter production does not occur over the study site, although there is a small peak in organic matter flux during summer (Romero et al., 2002; Muller and Fischer, 2003). Secondly, core-top C. wuellerstorfi $\delta^{13} \mathrm{C}$ values of nearby cores GeoB1721-5, GeoB1719-4 and GeoB1729-2 are within $0.15 \%$ of bottom water $\delta^{13} \mathrm{C} \Sigma \mathrm{CO}_{2}$, suggesting that unlike sites closer to the coastal upwelling cells, a photodetritus effect does not arise from enhanced pro- ductivity in more open-ocean locations (Bickert and Wefer, 1999). Uvigerina spp. calcify within sediment porewaters and thus may be biased by low- $\delta{ }^{13} \mathrm{C}$ metabolic carbon during organic matter oxidation (Zahn et al., 1986). However, 41 paired measurements of $C$. wuellerstorfi and Uvigerina spp. from Site-1085 and GeoB1720-2/3 give a $\delta^{13} \mathrm{C}$ difference of $+0.93 \%$ o (Fig. 4) which is close to the Duplessy et al. (1984) $+0.90 \%$ correction. Additionally, C. wuellerstorfi $\delta^{13} \mathrm{C}$ in nearby ODP Site-1088 (Pierre et al., 2001) $\left(41.8^{\circ} \mathrm{S}\right.$, $13.3^{\circ} \mathrm{E}, 2082 \mathrm{~m}$ ) (Fig. 3b) are extremely similar to Uvigerina spp. during MIS-12 in Site-1085, suggesting that these values may be reliably interpreted in terms of bottom water $\delta^{13} \mathrm{C}$. 
It is possible that small changes in air-sea carbon exchange in regions of NADW/GNAIW formation could affect benthic $\delta^{13} \mathrm{C}$ in Site-1085. NADW presently has an air-sea $\delta^{13} \mathrm{C}$ signature $\left(\delta^{13} \mathrm{C}_{a s}\right)$ of $-0.4 \%$ due to the invasion of atmospheric $\mathrm{CO}_{2}$ in regions of deepwater formation (Broecker and Maier-Reimer, 1992). A reduction in this flux, perhaps in response to an increase in surface water temperatures (reducing $\mathrm{CO}_{2}$ solubility) could therefore lead to an increase in deepwater $\delta^{13} \mathrm{C}$. This would require a reduction in $\mathrm{CO}_{2}$ invasion of $\sim 100 \mu \mathrm{mol} / \mathrm{kg}$ to explain $\sim+0.5 \% \circ \delta^{13} \mathrm{C}_{a s}$ (LynchStieglitz et al., 1995). However, an increase in surface temperatures would also alter the equilibrium between atmospheric and surface ocean carbon, simultaneously reducing $\delta^{13} \mathrm{C}_{a s}$ by $\sim 0.1 \%$ o ${ }^{\circ} \mathrm{C}$ (Lynch-Stieglitz et al., 1995). Without benthic $\mathrm{Cd} / \mathrm{Ca}$ measurements (e.g. Lynch-Stieglitz and Fairbanks, 1994), it is difficult to tell what the net effect of these processes would have on the Site-1085 $\delta^{13} \mathrm{C}$ data. The assumption is made that changes in air-sea exchange are less significant than the influence of ocean circulation on benthic $\delta^{13} \mathrm{C}$ and thus do not adversely affect the interpretations that follow.

\subsection{Glacial-interglacial changes in benthic $\delta^{13} \mathrm{C}$}

Deep sites within the Cape Basin have more negative benthic foraminifera $\delta^{13} \mathrm{C}$ values than the deep Pacific Ocean during late Pleistocene glacials (Raymo et al., 1990; Oppo and Horowitz, 2000; Ninnemann and Charles, 2002; Hodell et al., 2003a). In contrast, benthic $\delta^{13} \mathrm{C}$ in Site-1085 reaches $+0.8-0.9 \%$ during MIS-11 and $+0.1-0.2 \%$ during MIS-10 and 12 , and never falls below the deep Pacific $\delta^{13} \mathrm{C}$ values recorded at ODP Site-849 (Mix et al., 1995) (Fig. 3b). The average glacial-interglacial $\delta^{13} \mathrm{C}$ change between the MIS11 climate optimum (424-397 ka) and MIS-10 (360-340 ka) is $-0.34 \%$ which is similar in amplitude to the $+0.32 \%$ o glacial-interglacial change in whole-ocean $\delta^{13} \mathrm{C}$ due to expansions and contractions of the terrestrial biosphere seen over the MIS-2/1 transition (Curry et al., 1988), but less than the $+0.95 \%$ proposed for the MIS-12/11 boundary (Thunell et al., 2002). Consequently, it may be surmised that a lownutrient water mass with similar $\delta^{13} \mathrm{C} \Sigma \mathrm{CO}_{2}$ values to the present NADW/UCDW mixture must have been present at $\sim 1700 \mathrm{~m}$ depth during glacial stages MIS-10 and 12 in the South East Atlantic Ocean at $30^{\circ} \mathrm{S}$. Slightly higher $\delta^{13} \mathrm{C}$ values at Site-1088 between 360-340 ka (Pierre et al., 2001) probably reflect increased mixing with underlying CDW during full glacial conditions (Fig. 3b).

The source of the low-nutrient water mass that overlay Site-1085 during MIS-10 and 12 may be sought through a comparison to several studies that have shown the presence of a sharp chemocline in the South Atlantic and adjacent Southern Ocean during glacial periods (Ninnemann and Charles, 2002; Hodell et al., 2003a). This chemocline separated low-nutrient (high $\delta^{13} \mathrm{C}$ ) water above $2100 \mathrm{~m}$ from

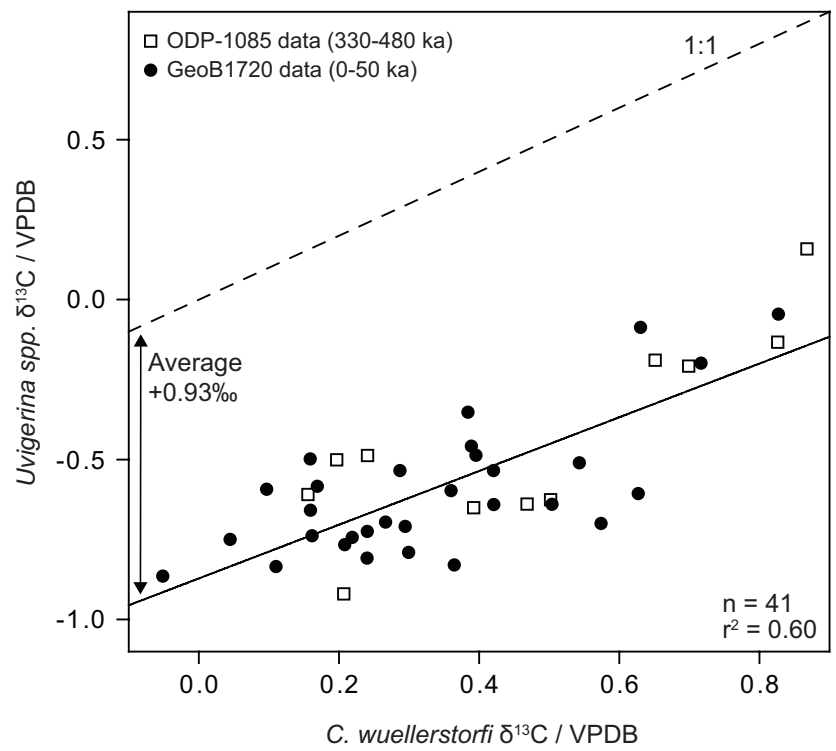

Fig. 4. Paired C. wuellerstorfi/Uvigerina $\delta^{13} \mathrm{C}$ data from Site-1085 and GeoB-1720-2 showing an average $0.93 \%$ o difference.

high-nutrient (low $\delta^{13} \mathrm{C}$ ) water below. The presence of a low-nutrient water mass at intermediate depths $<2100 \mathrm{~m}$ can also be traced along the African continental slope (Pierre et al., 2001; Mackensen et al., 2001) and into the western South Atlantic Ocean, where it has been identified as a water mass with $\delta^{13} \mathrm{C}$ values $>+0.8 \%$ o centred at $\sim 1500 \mathrm{~m}$ depth and bounded above and below by higher-nutrient water masses (Oppo and Horowitz, 2000; Curry and Oppo, 2006). A glacial chemocline at $2000 \mathrm{~m}$ depth has also been identified in the North Atlantic (Oppo and Lehmann, 1993), and is related to the production of GNAIW and the northwards spread of low $\delta^{13} \mathrm{C}$ southern sourced deepwaters below the minimum depth of the mid-Atlantic ridge (Curry and Oppo, 2006). Based on the similarity of $\delta^{13} \mathrm{C}$ values, the consistency with existing reconstructions of glacial water mass geometry, and the consistency with modern oceanographic observations of a divergence of NADW flow from the western to the eastern South Atlantic south of the Equator, bottom waters over Site-1085 during MIS-10 and 12 were likely influenced by GNAIW, and not the Sub-Antarctic Mode Water (SAMW) suggested by Hodell et al. (2003a).

\subsection{Millennial-scale changes in benthic $\delta^{13} \mathrm{C}$}

The temporal resolution of the Site-1085 dataset allows millennial-scale changes in deepwater $\delta^{13} \mathrm{C}$ to be identified (shaded bands in Fig. 3). These events are most pronounced during the transition from MIS-11 into MIS-10 (397$340 \mathrm{ka}$ ), when their amplitude ranges from +0.1 to $+0.3 \%$ o. Each event is superimposed onto the glacial-interglacial $\delta^{13} \mathrm{C}$ 
Table 2. Core sites with benthic $\delta^{13} \mathrm{C}$ data resolution $\leq 500 \mathrm{yr}$ used in this study.

\begin{tabular}{lllll}
\hline Core & Location & Depth & Average $\delta^{13} \mathrm{C}$ data resolution & Reference \\
\hline ODP-1085 & $29.2^{\circ} \mathrm{S}, 13.6^{\circ} \mathrm{E}$ & $1713 \mathrm{~m}$ & $450 \mathrm{yr}$ & This study \\
ODP-980 & $55.3^{\circ} \mathrm{N}, 14.4^{\circ} \mathrm{W}$ & $2170 \mathrm{~m}$ & $380 \mathrm{yr}$ & Oppo et al. (1998), McManus et al. (1999) \\
ODP-1089 & $47.6^{\circ} \mathrm{S}, 9.5^{\circ} \mathrm{E}$ & $4621 \mathrm{~m}$ & $380 \mathrm{yr}$ & Hodell et al., (2003a, b) \\
ODP-1063 & $33.4^{\circ} \mathrm{N}, 57.4^{\circ} \mathrm{W}$ & $4583 \mathrm{~m}$ & $520 \mathrm{yr}$ & Poli et al. (2000) \\
\hline
\end{tabular}

Table 3. Age control points for each core.

\begin{tabular}{lllll}
\hline $\begin{array}{l}\text { LR04 } \\
\text { age/ka }\end{array}$ & $\begin{array}{l}\text { ODP-1085 } \\
\text { depth/mbsf }\end{array}$ & $\begin{array}{l}\text { ODP-1089 } \\
\text { depth/mcd }\end{array}$ & $\begin{array}{l}\text { ODP-980 } \\
\text { depth/mcd }\end{array}$ & $\begin{array}{l}\text { ODP-1063 } \\
\text { depth/mcd }\end{array}$ \\
\hline 341 & 11.41 & 50.96 & - & 77.44 \\
348 & 11.94 & - & 45.64 & - \\
354 & 12.36 & 53.6 & 46.74 & 80.04 \\
364 & 12.84 & - & - & - \\
372 & - & - & 48.27 & - \\
382 & - & 58.57 & - & - \\
385 & 13.71 & - & 49.94 & - \\
394 & - & 60.92 & 51.39 & 88.6 \\
397 & 14.24 & 61.67 & 52.16 & 89.09 \\
424 & 15.76 & 64.27 & 56.41 & 90.82 \\
430 & 15.98 & - & - & - \\
431 & - & 65.52 & 58.00 & 91.45 \\
441 & - & 66.72 & - & - \\
447 & - & - & 60.22 & - \\
455 & 16.61 & - & 61.07 & 95.33 \\
471 & 17.30 & - & 62.67 & 100.75 \\
491 & - & - & 64.31 & 107.81 \\
\hline
\end{tabular}

trend, over timescales that are too short to be explained by terrestrial biosphere expansions. Supplementary information about the balance between CDW and northern-sourced waters (either NADW in the modern sense or GNAIW in the glacial sense) over the core site may be obtained from a measure of calcium carbonate preservation. Contemporary observations indicate that NADW has a higher alkalinity than CDW. This distribution of alkalinity affects the preservation of calcium carbonate in the deep sea, since the carbonate lysocline will be deeper in regions overlain by NADW (Broecker, 2003). Each millennial increase in benthic $\delta^{13} \mathrm{C}$ corresponds to a small decrease in the abundance and accumulation rate of planktonic foraminifera fragments in Site-1085 (Fig. 3c), which would be expected if the carbon isotope change were being caused by the mixing of NADW/GNAIW with CDW. This relationship is not straightforward because of a number of factors that can also influence calcium carbonate dissolution, such as changes in the population of foraminifera species (e.g. Berger, 1970) and the release of metabolic $\mathrm{CO}_{2}$ in sediment porewaters (Broecker, 2003).
The millennial-scale increases in benthic $\delta^{13} \mathrm{C}$ during MIS-10 to 12 were likely caused either by less NADW(GNAIW)/CDW mixing (deepening of the GNAIW/CDW boundary), or by an increase in preformed $\delta^{13} \mathrm{C}$ of GNAIW entering the intermediate-depth Cape Basin. Higher flux rates of GNAIW could reduce its residence time in the western Atlantic, thus increasing pre-formed $\delta^{13} \mathrm{C}$ in the South East Atlantic, in agreement with studies showing an enhanced export of this water mass from the North Atlantic during the LGM (Yu et al., 1996; Oppo and Horowitz, 2000). In either case, the data from Site-1085 point to periodically enhanced transport of GNAIW into the South Atlantic due to higher flux rates or higher mass transport.

\subsection{Comparison to the North Atlantic and the Southern Ocean records}

The benthic foraminifera $\delta^{13} \mathrm{C}$ record from Site-1085 may be compared to other high-resolution datasets covering the period 330-480 ka from the North and South Atlantic Ocean in order to identify basin-wide responses to deep-ocean circulation changes. To maximise the potential for examining sub-orbital variability, only datasets with a temporal resolution of $\leq 500 \mathrm{yr}$ have been used in our comparison. Details of these cores are shown in Table 2. Briefly, ODP Site980 and ODP Site-1063 monitor changes in UNADW and LNADW respectively (Oppo et al., 1998; McManus et al., 1999; Poli et al., 2000; Thunell et al., 2002), while ODP Site1089 is located within LCDW in the southern Cape Basin, south of Site-1085 (Hodell et al., 2001). Each record has been placed on a common age-scale by tying benthic $\delta^{18} \mathrm{O}$ to the LR04 stack (Lisiecki and Raymo, 2005) (Fig. 5a and Table 3). This procedure allows an internal comparison to be made within the precision allowed by stratigraphic correlation ( 2000 yr). Sites-1085, 980 and 1089 have been interpolated at $500 \mathrm{yr}$ intervals to calculate inter-site gradients. The North Atlantic-South Atlantic gradient has been calculated as $\Delta(980-1085)$ (Fig. 5c), and the vertical Cape Basin gradient has been calculated as $\Delta(1085-1089)$ (Fig. 5d). Our selection of records with a high temporal resolution means that changes in water mass end-member values may have affected inter-site the $\delta^{13} \mathrm{C}$ gradients. However, these changes also provide information about the phasing of different modes of deepwater circulation. 


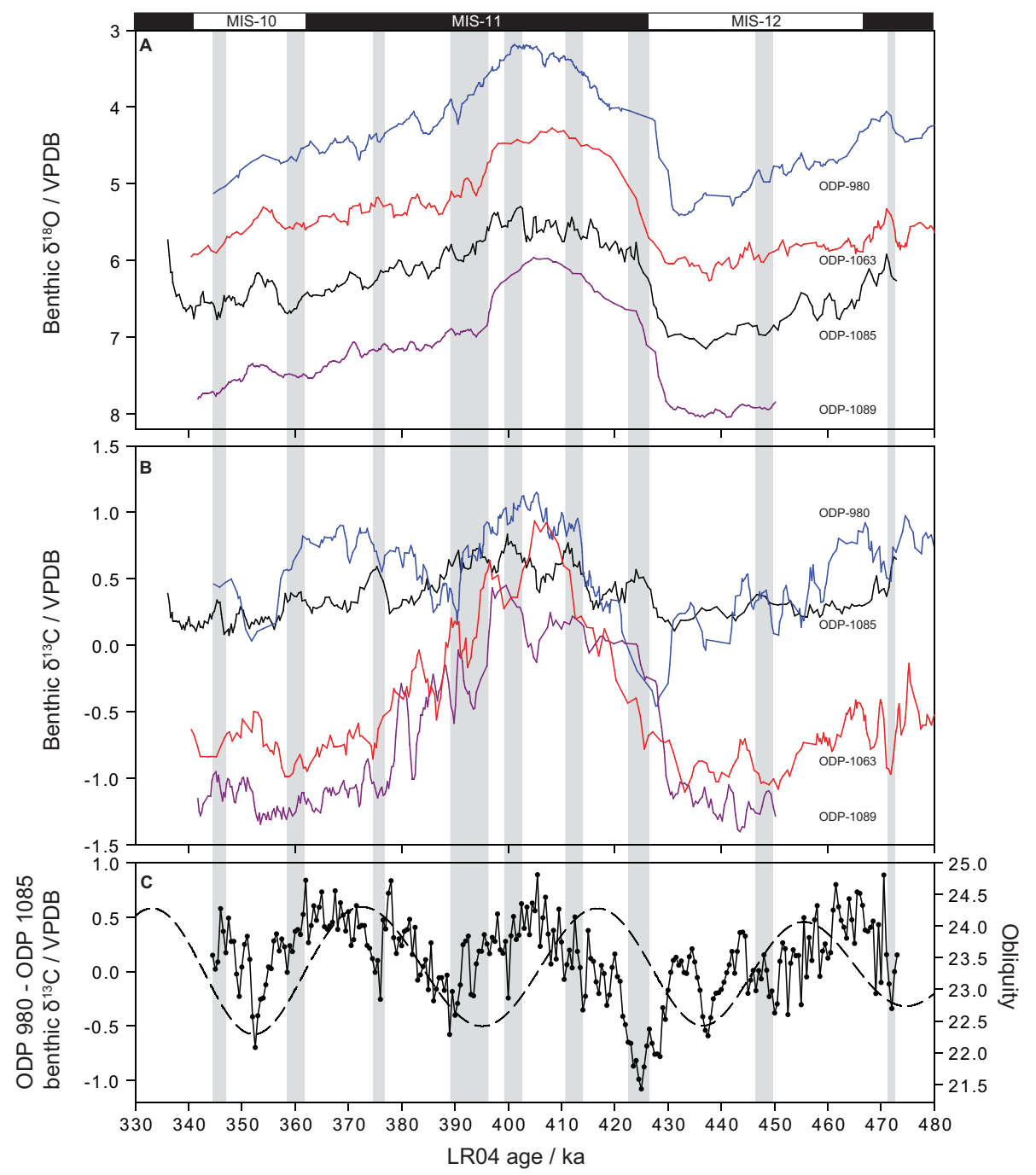

Fig. 5. Sub-millennial resolution benthic carbon isotope data for Atlantic Ocean sites aligned on the LR04 timescale. (a) Benthic $\delta^{18} \mathrm{O}$ (5-point running averages). For clarity, the data are offset by $+1 \%$ o (Site-1063), $+2 \%$ (Site-1085) and $+3 \%$ (Site-1089). (b) Benthic $\delta^{13} \mathrm{C}$ (5-point running averages). (c) North-South Atlantic $\delta^{13} \mathrm{C}$ gradient calculated from Site-980-Site-1085, plotted with obliquity (dashed line, Berger and Loutre, 1991). Shaded vertical bands as in Fig. 3.

\subsection{1 $\Delta(980-1085) \delta^{13} \mathrm{C}$ gradient}

Assuming that the $\delta^{13} \mathrm{C} \Sigma \mathrm{CO}_{2}$ of CDW is primarily controlled by mixing with NADW (Charles et al., 1996; Ninnemann and Charles, 2002), the $\delta^{13} \mathrm{C}$ gradient between NADW source regions and the South Atlantic/Southern Ocean should provide a measure of the southward flux of NADW and thus the relative strength of northern hemisphere deepwater production (Oppo et al., 1990; Raymo et al., 1990). From Fig. 5c, $\Delta(980-1085)$ values become lower on several occasions, suggesting an increase in the flux of NADW/GNAIW into the South Atlantic. A strong $41000 \mathrm{yr}$ periodicity (Fig. 6) is consistent with the modulation of intermediate-depth ventilation by changes in high-latitude climatic boundary conditions (Ruddiman and McIntyre, 1984; Raymo et al., 1990). Presumably, at times of low obliquity increases in ice-volume would increase the delivery of meltwater to sites of deepwater overturning, inhibiting deep-ventilation at the expense of a strengthened intermediate circulation cell (e.g. Marchitto et al., 1998).

Negative values of $\Delta 980-1085$ occur at $360 \mathrm{ka}, 375 \mathrm{ka}$, $390 \mathrm{ka}, 425 \mathrm{ka}$ and $438 \mathrm{ka}$, which would suggest a reversal of the modern north-south Atlantic $\delta^{13} \mathrm{C}$ gradient if end-member values remained constant. These reversals are partially due to increases in benthic $\delta^{13} \mathrm{C}$ in Site-1085 (Fig. 3b) and decreases in benthic $\delta^{13} \mathrm{C}$ in Site-980 (Fig. 5b), which was sensitive to shoaling of the GNAIW/Southern Component Water (SCW) boundary during the last glacial 


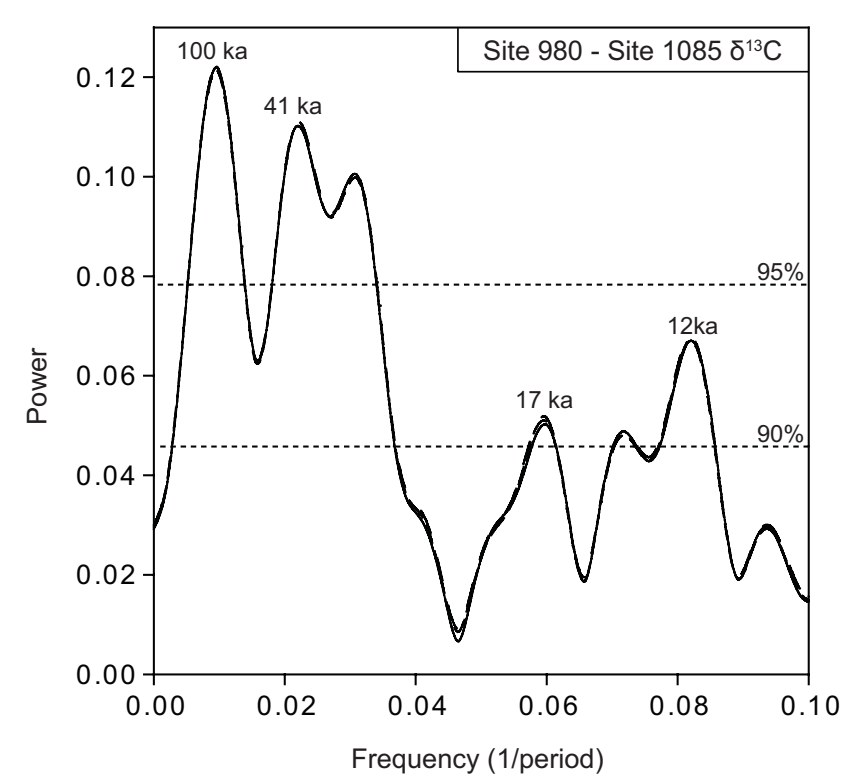

Fig. 6. Spectral response of the $\Delta(980-1085) \delta^{13} \mathrm{C}$ gradient, calculated using the MC-Clean 2.0 MATLAB algorithm of Heslop and Dekkers (2002). The horizontal lines indicates the $95 \%$ and $90 \%$ confidence level across all frequencies estimated from a series of spectra generated from white noise applied to the input time series.

period (Oppo and Lehmann, 1993). Millennial-scale increases in the penetration of SCW into the North Atlantic at the expense of LNADW can also be found in benthic $\delta^{13} \mathrm{C}$ isotope decreases in deep western Atlantic site Site-1063 (Poli et al., 2000; Fig. 5b), and from increases in sortable silt grain size related to shoaling of the LNADW-derived Deep Western Boundary Current in ODP Site-1061 (Hall and Becker, 2007). These events correspond particularly well at $360 \mathrm{ka}, 375 \mathrm{ka}, 390 \mathrm{ka}$ and $470 \mathrm{ka}$. Consequently, it may be surmised that the flux/mass of GNAIW to the South East Atlantic Ocean increased during periods when several sites suggest less LNADW production and/or more SCW production. This anti-phased relationship was also present during the most recent glacial termination (Marchitto et al., 1998). Since UNADW/GNAIW differs from LNADW by containing a component of Labrador Sea Water (LSW) in addition to the Greenland-Scotland Overflow Waters (GSOW) that are common to both (van Aken, 2000), the contrasting behaviour of these water masses through the study period points towards a strong variability of deepwater production in the Nordic Seas over millennial timescales during MIS-10 and 12.

Several studies have suggested that MIS-11 was an extremely stable interglacial, with little variability in surface water mass temperature and salinity in the North Atlantic (e.g. Oppo et al., 1998; McManus et al., 2003). However, two decreases in the $\Delta(980-1085)$ gradient at $412 \mathrm{ka}$ and $402 \mathrm{ka}$ occur alongside increases in benthic $\delta^{13} \mathrm{C}$ in Site1085 and show that the Southeast Atlantic NADW/UCDW boundary shoaled at these times. Similar benthic $\delta^{13} \mathrm{C}$ values in Sites-1089 and 1063 (Fig. 5b) suggest that the LCDW/NADW boundary also shoaled during these events, allowing southern-sourced deepwater to spread into the abyssal North Atlantic. There was little IRD deposition in the North Atlantic during 410-390 ka (Oppo et al., 1998; Helmke and Bauch, 2003), which would tend to argue against changes in NADW production. In contrast, there is some evidence of a regional cooling in the Southern Ocean at 410-415 ka (Becquey and Gersonde, 2002; Cortese et al., 2007). One possibility is that the westerly winds surrounding Antarctica were displaced slightly equatorwards by this cooling, thus weakening the Antarctic Circumpolar Current and reducing the amount of deepwater upwelling (Toggweiler and Russell, 2008). Such a reduction could have weakened the intensity of southwards NADW flux, explaining the $\delta^{13} \mathrm{C}$ changes observed at this time in the abyssal Atlantic. However, more detailed palaeoclimatic information from the Southern Ocean would be needed to test this suggestion.

\subsection{2 $\Delta 1085-1089 \delta^{13} \mathrm{C}$ gradient}

The concentration of atmospheric $\mathrm{CO}_{2}$ during late Pleistocene glacial periods was $\sim 80 \mathrm{ppm}$ lower than during interglacials (e.g. Petit et al., 1999). A number of mechanisms probably combined to produce this change, involving physical changes in ocean temperature, salinity, circulation and mixing, changes in the export of organic carbon to the deep sea, and changes in deep-ocean alkalinity (e.g. Toggweiler, 1999; Stephens and Keeling, 2000; Sigman and Boyle, 2000; Marinov et al., 2006; Broecker, 2003; Sigman and Haug, 2003). To examine the relevance of deepwater ventilation changes on atmospheric $\mathrm{CO}_{2}$ during MIS-12 to 10 , a similar approach to Hodell et al. (2003a) is used, whereby the benthic $\delta^{13} \mathrm{C}$ gradient between high-resolution intermediate water Site-1085 and high-resolution deepwater Site-1089 is calculated at $500 \mathrm{yr}$ intervals between $\sim 450 \mathrm{ka}$ and $340 \mathrm{ka}$. Despite geographical distance, both sites are located within the Cape Basin north of the Subtropical Front, and are characterised by $\sim 70 \% \mathrm{CaCO}_{3}$ concentrations during glacials.

The vertical Cape Basin $\delta^{13} \mathrm{C}$ gradient shown in Fig. 7 closely corresponds to the spliced EPICA Dome C/Vostok atmospheric $\mathrm{CO}_{2}$ record (Petit et al., 1999; Siegenthaler et al., 2005), in agreement with suggestions that the glacial chemocline that formed at $\sim 2 \mathrm{~km}$ in the Southern Ocean represents a shift in oceanographic conditions that impacted strongly on atmospheric $\mathrm{CO}_{2}$ concentrations (Ninnemann and Charles, 2002; Hodell et al., 2003a; Mortyn et al., 2003). From Fig. 7, the first $\sim 0.5 \%$ increase in $\Delta \delta^{13} \mathrm{C}$ took place at $397 \mathrm{ka}$, accompanying a $30 \mathrm{ppm}$ decrease in $\mathrm{CO}_{2}$ to fairly stable intermediate levels of $\sim 250 \mathrm{ppm}$. The chemical divide then reached its maximum at $377 \mathrm{ka}$ following a second abrupt rise in $\Delta \delta^{13} \mathrm{C}$, thus leaving other mechanisms to explain the remaining $45 \% \circ \mathrm{CO}_{2}$ drop. Carbonate deposition continued to increase alongside an increase in carbonate preservation 


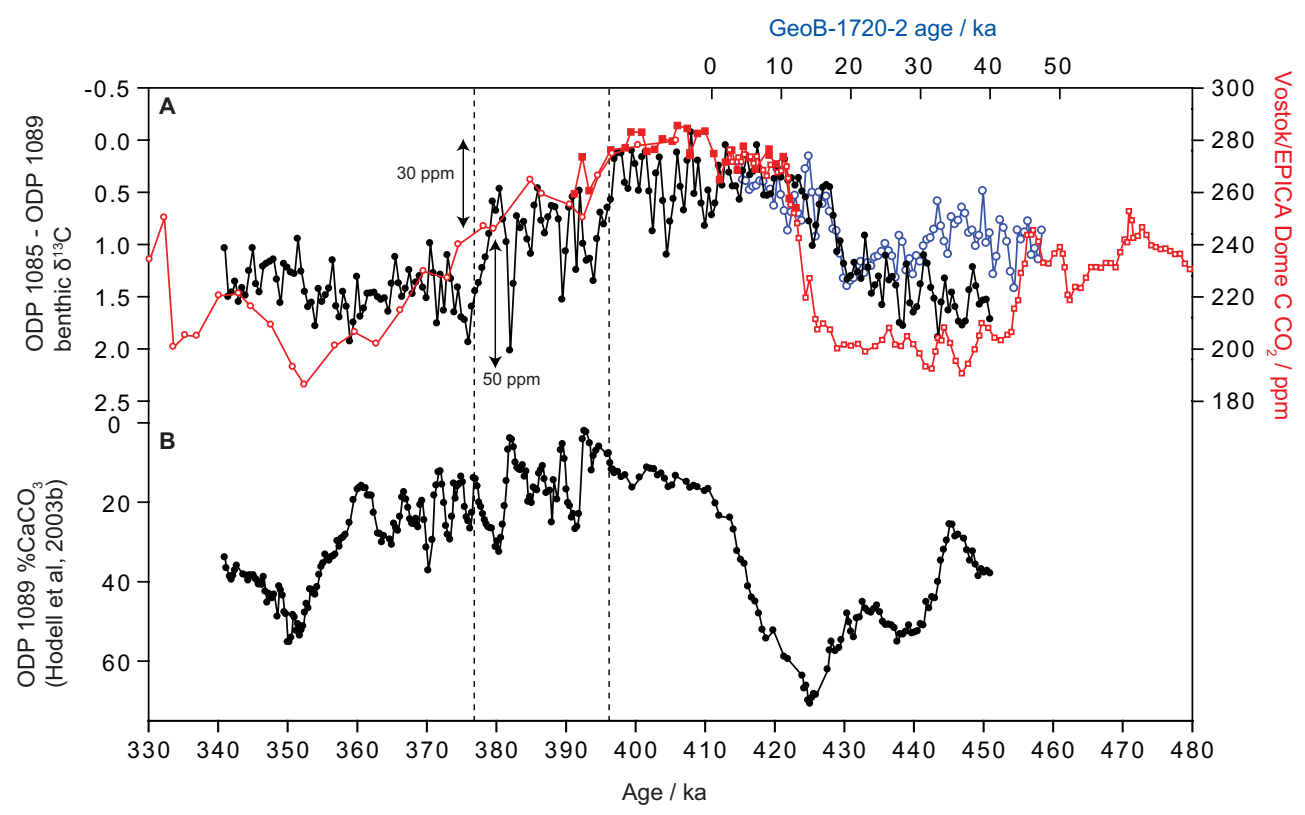

Fig. 7. Cape Basin benthic $\delta^{13} \mathrm{C}$ gradients and atmospheric $\mathrm{CO}_{2}$. (a) Intermediate-deep Cape Basin $\delta^{13} \mathrm{C}$ gradient calculated from Site1085-Site-1089 (black), plotted alongside the spliced Vostok (open red circles)/EDC (open and closed red squares) $\mathrm{CO}_{2}$ record on the EDC2 gas age timescale (Petit et al., 1999; Siegenthaler et al., 2005). The intermediate-deep $\delta^{13} \mathrm{C}$ gradient calculated for the last $50000 \mathrm{yr}$ from GeoB-1720-2-Site-1089 is shown for comparison (open blue circles) on its own ${ }^{14} \mathrm{C}$ age-scale (inset horizontal axis). The latter record has been positioned by aligning the steep deglacial decreases in $\delta^{13} \mathrm{C}$, rather than orbital parameters (e.g. Ruddiman, 2005), as the objective is to compare the magnitude of change over the two terminations rather than the timing. (b) $\% \mathrm{CaCO}_{3}$ data from Site-1089 (Hodell et al., $2003 \mathrm{~b}$ ).

after 375 ka in Site-1089 (Fig. 7) (Hodell et al., 2001; 2003b). Consequently, the effects of deep-ocean alkalinity change may have become more important than deep-ocean ventilation in forcing $\mathrm{CO}_{2}$ change later during the transition into MIS-10.

Toggweiler (1999) suggested that an interglacial-glacial shift of $-80 \mathrm{ppm}$ in atmospheric $\mathrm{CO}_{2}$ could be forced by the reduced ventilation of the deep ocean $(-21 \mathrm{ppm})$, along with a decrease in SST and an increase in deep-ocean alkalinity $(-59 \mathrm{ppm})$. The sequence of events suggested by Toggweiler (1999) was that the change in deep-ocean ventilation would impact on $\mathrm{CO}_{2}$ first, followed by SST and carbonate compensation. A similar sequence of events was proposed by Peacock et al. (2006), who used a box model to suggest that in order to avoid the timing constraints imposed by sealevel change, reduced glacial sea-surface temperatures and reduced high-latitude vertical mixing could explain up to $50 \mathrm{ppm}$ of the initial $\mathrm{CO}_{2}$ drop leading into MIS-5a to $5 \mathrm{~d}$. Alkalinity and nutrient changes could then explain the second part of the $\mathrm{CO}_{2}$ decline leading into MIS-4. The range of $\mathrm{CO}_{2}$ found to accompany the initial change in $\Delta(1085$ 1089) ( $\sim 30 \mathrm{ppm})$ is similar to the $21 \mathrm{ppm}$ modelled by Toggweiler (1999), and therefore supports the role of deep-ocean ventilation as the initial driver of $\mathrm{CO}_{2}$ decline following the MIS-11 climate optimum.
McManus et al. (1999) suggested that millennial-scale climate variability increases when benthic $\delta^{18} \mathrm{O}$ reaches a value of $+3.5 \%$ o (or $+4.14 \%$ o when corrected for equilibrium effects). The period of "intermediate" $\delta^{13} \mathrm{C}$ stratification in the Cape Basin between 392-378 ka occurs when benthic foraminifera $\delta^{18} \mathrm{O}$ in Site-1085 reaches this threshold, thus suggesting that periods of intermediate ice-volume were also characterised by a unique configuration of water masses in the South Atlantic/Southern Ocean, and a correspondingly unique mode of ocean circulation.

Recent ice-core data has revealed that despite a large amount of deep-ocean carbonate dissolution during MIS11 (e.g. Zeigler et al., 2003), atmospheric $\mathrm{CO}_{2}$ concentrations were broadly similar to the Holocene (Siegenthaler et al., 2005). In agreement with this, the vertical $\delta^{13} \mathrm{C}$ gradient between GeoB1720-2 (near to Site-1085 at $1995 \mathrm{~m}$ depth) and Site-1089 has an almost identical magnitude of change over termination 1 as during termination 5 , and similar interglacial values (Fig. 6, blue circles). However, the $\delta^{13} \mathrm{C}$ gradient was $\sim 1 \%$ o higher during MIS-12 than during MIS-2, yet $\mathrm{CO}_{2}$ concentrations were, if anything, 5-10 ppm higher during the former glacial period (Siegenthaler et al., 2005). This discrepancy may be due to the slightly deeper depth of GeoB1720-2 that makes it more sensitive to mixing with CDW during glacials, as seen for Site-1088 (Fig. 3b). These observations reinforce the proposed role of the South- 
ern Ocean stratification in contributing to changes in atmospheric $\mathrm{CO}_{2}$ (Toggweiler, 1999; Hodell et al., 2003a), and also show that the position of the South Atlantic/Southern Ocean chemocline was located slightly shallower than $2 \mathrm{~km}$ during full glacial stages MIS-12, MIS-10 and MIS-2.

\section{Conclusions}

Intermediate water $\delta^{13} \mathrm{C}$ variability at Site-1085 was extremely muted between $\sim 480-330 \mathrm{ka}$ and can be explained by the continuous influence of northern sourced deepwaters during glacials MIS-10 and MIS-12 (GNAIW) and interglacial MIS-11 (NADW). During glacials, millennialscale increases in benthic $\delta^{13} \mathrm{C}$ match small decreases in foraminifera fragmentation and imply either an increased flux of GNAIW to the South East Atlantic, or a decrease in the amount of mixing with adjacent CDW due to a temporary deepening of the South Atlantic glacial chemocline. These events correspond to shoaling of the GNAIW/SCW boundary in the north Atlantic, and imply an anti-phased relationship at millennial timescales between the production North Atlantic deepwaters in the Greenland and Labrador Seas respectively. During MIS-11, millennial-scale increases in benthic $\delta^{13} \mathrm{C}$ indicate shoaling of the NADW/UCDW boundary. From comparison to other published core sites, this may reflect the increased penetration of southern-sourced deepwaters into the abyssal North Atlantic Ocean, although the cause of these events remains uncertain.

Our data also reveals that the detailed vertical Cape Basin $\Delta \delta^{13} \mathrm{C}$ gradient parallels atmospheric $\mathrm{CO}_{2}$ concentrations derived from the EPICA Dome $\mathrm{C}$ and Vostok ice cores. This supports previous suggestions that a strong chemical divide in the glacial Southern Ocean was able to isolate nutrient and $\mathrm{CO}_{2}$-rich deepwaters and thus contribute to glacial $\mathrm{CO}_{2}$ drawdown (Toggweiler, 1999; Hodell et al., 2003a), although this mechanism may have been most important during the initial phases of $\mathrm{CO}_{2}$ decline following the warmest part of MIS-11. The similarity in the magnitude of the $\delta^{13} \mathrm{C}$ gradient shift over terminations 1 and 5 matches the similar magnitude of $\mathrm{CO}_{2}$ change observed over each transition (Siegenthaler et al., 2005) and strongly implicates the Southern Ocean as an important store of $\mathrm{CO}_{2}$ during Middle-Pleistocene glacial periods. Its potential importance for sub-orbital $\mathrm{CO}_{2}$ changes awaits more detailed gas measurements from the Antarctic ice-core records.

Acknowledgements. The authors wish to thank Hilary Sloane for running the mass spectrometer at NIGL, Torsten Bickert for kindly providing water-column data from GeoB-1202, Amelia Shevenell for commenting on an early draft of the manuscript, J. McManus for editorial corrections, and two anonymous reviewers whose suggestions improved the final draft. This work was supported by a NERC PhD studentship award to AJD (NER/S/A/2005/13226) and NIGFSC grant IP/894/0506.

Edited by: J. McManus

\section{References}

Becquey, S. and Gersonde, R.: A 0.55-Ma paleotemperature record from the Subantarctic zone: Implications for Antarctic Circumpolar Current development, Paleoceanography, 18, 1014, doi:10.1029/2000PA000576, 2002.

Belanger, P. E., Curry, W. B., and Matthews, R. K.: Core-top evaluation of benthic foraminiferal isotopic ratios for paleooceanographic interpretations, Palaeogeogr. Palaeocl., 33, 205220, 1981.

Berger, A. and Loutre M. F.: Insolation values for the climate of the last 10 million of years, Quaternary Sci. Rev., 10, 297-317, 1991.

Berger, A.: Planktonic foraminifera - selective solution and lysocline, Mar. Geol., 8, 111-138, 1970.

Bickert, T. and Wefer, G.: South Atlantic and benthic foraminifer ${ }^{13} \mathrm{C}$ deviations: implications for reconstructing the late Quaternary deep water circulation, Deep-Sea Res. Pt. II, 46, 437-452, 1999.

Boyle, E. A. and Keigwin, L. D.: Comparison of Atlantic and Pacific paleochemical records for the last 215000 years: changes in deep ocean circulation and chemical inventories, Earth Planet. Sc. Lett., 76, 135-150, 1985/86.

Boyle, E. A. and Keigwin, L. D.: North Atlantic thermohaline circulation during the last 20000 years: link to high latitude surface temperature, Nature, 330, 35-40, 1987.

Broecker, W. S.: The oceanic $\mathrm{CaCO}_{3}$ cycle, in: Treatise in Geochemistry, edited by: Holland, H. D. and Turekian, K. K., Elsevier, 6, 539-549, 2003.

Broecker, W. S. and Henderson, G. M.: The sequence of events surrounding termination II and their implications for the cause of glacial-interglacial $\mathrm{CO}_{2}$ changes, Paleoceanography, 13, 352364, 1998.

Broecker, W. S. and Maier-Reimer, E.: The influence of air and sea exchange on the carbon isotope distribution in the sea, Global Biogeochem. Cy., 6, 315-320, 1992.

Charles, C. D., Lynch-Steiglitz, J., Ninnemann, U., and Fairbanks, R. G.: Climate connections between the hemisphere revealed by deep sea sediment core/ice core correlations, Earth Planet. Sc. Lett., 142, 19-27, 1996.

Clark, P. U., Pisias, N. G., Stocker, T. F., and Weaver, A. J.: The role of the thermohaline circulation in abrupt climate change, Nature, 415, 863-869, 2002.

Cortese, G., Abelmann, A., and Gersonde, R.: The last five glacialinterglacial transitions: A high resolution 450 000-year record from the subantarctic Atlantic, Paleoceanography, 22, PA4203, doi:10.1029/2007PA001457, 2007. 
Curry, W. B., Duplessy, J. C., Labeyrie, L. D., and Shackleton, N. J.: Changes in the distribution of $\delta^{13} \mathrm{C}$ of deep water $\Sigma \mathrm{CO}_{2}$ between the last glaciation and the Holocene, Paleoceanography 3, 31341, 1988.

Curry, W. B. and Lohmann, G. P.: Reduced advection into Atlantic Ocean deep eastern basins during last glacial maximum, Nature, 306, 577-580, 1983.

Curry, W. B. and Oppo, D. W.: Glacial water mass geometry and the distribution of $\delta^{13} \mathrm{C}$ of $\mathrm{CO}_{2}$ in the western Atlantic Ocean, Paleoceanography, 20, PA1017, doi:10.1029/2004PA001021, 2005.

Duplessy, J. C., Shackleton, N. J., Fairbanks, R. G., Labeyrie, L., Oppo D., and Kallel, N.: Deepwater source variations during the last climatic cycle and their impact on the global deepwater circulation, Paleoceanography, 3, 343-360, 1988.

Duplessy, J. C., Shackleton, N. J., Matthews, R. K., Prell, W., Ruddiman, W. F., Caralp, M., and Hendy, C. H.: ${ }^{13} \mathrm{C}$ record of benthic foraminifera in the last interglacial ocean: implications for the carbon cycle and the global deep water circulation, Quaternary Res., 21, 225-243, 1984.

Graham, D. W., Corliss, B. H., Bender, M. L., and Keigwin Jr, L. D.: Carbon and oxygen isotopic disequilibria of recent deep sea benthic foraminifera, Mar. Micropaleontol., 6, 483-497, 1981.

Hall, I. R. and Becker, J.: Deep western Boundary Current variability in the subtropical Northwest Atlantic during Marine Isotope Stages 12-10. Geochem. Geophy. Geosy., 8, Q06013, doi:10.1029/2006GC001518, 2007.

Helmke, J. P. and Bauch, H. A.: Comparison of glacial and interglacial conditions between the polar and subpolar North Atlantic region over the last five climatic cycles, Paleoceanography, 18, 1036, doi:10.1029/2002PA000794, 2003.

Heslop, D. and Dekkers, M. J.: Spectral analysis of unevenly spaced climatic time series using CLEAN: signal recovery and derivation of significance levels using a Monte-Carlo simulation, Phys. Earth Planet. In., 130, 103-116, 2002.

Hodell, D. A., Charles, C. D., and Sierro, F. J.: Late Pleistocene evolution of the ocean's carbonate system, Earth Planet. Sc. Lett., 192, 109-124, 2001.

Hodell, D. A., Venz, K. A., Charles, C. D., and Ninnemann, U. S.: Pleistocene vertical carbon isotope and carbonate gradients in the South Atlantic sector of the Southern Ocean, Geochem. Geophy. Geosy., 4, 1004, doi:10.1029/2002GC000367, 2003a.

Hodell, D. A. kanfoush, S. Venz, K. A. And Charles, C. D.: The Mid-Brunhes transition in ODP sites 1989 and 1090 (Subantarctic South Atlantic), in: Earth's climate and orbital eccentricity: the marine isotope stage 11 question, edited by: Droxler, A. W., Poore, R. Z., and Buckle, L. H., AGU Geophysical Monograph, 137, 113-129, 2003b.

Kroopnick, P.: The distribution of $\delta^{13} \mathrm{C}$ in the Atlantic Ocean, Earth Planet. Sc. Lett., 49, 469-484, 1980.

Le, J. and Shackleton, N. J.: Carbonate dissolution fluctuations in the western Equatorial Pacific during the late Quaternary, Paleoceanography, 7, 21-42, 1992.

Lisiecki, L. E. and Raymo, M. E.: A Plio-Pleistocene stack of 57 globally distributed benthic $\delta^{18} \mathrm{O}$ records, Paleoceanography, 20, PA1003, doi:10.1029/2004PA001071, 2005.

Loutre, M-F. and Berger, A.: Marine Isotope Stage 11 as an analogue for the present interglacial. Global Planet. Change, 36, 209-217, 2003.
Lynch-Stieglitz, J. and Fairbanks, R. G.: A conservative tracer for glacial ocean circulation from carbon isotope and paleo-nutrient measurements in benthic foraminifera, Nature, 369, 308-310, 1994.

Lynch-Stieglitz, J., Stocker, T. F., Broecker, W. S., and Fairbanks, R. G. : The air-sea exchange on the isotopic composition of oceanic carbon: observations and modeling, Global Biogeochem. Cy., 9, 653-665, 1995.

Lynch-Stieglitz, J., Adkins, J. F., Curry, W. B., Dokken, T., Hall, I. R., Herguera, J. C., Hirschi, J. J. M., Ivanova, E. V., Kissel, C., Marchal, O, Marchitto, T. M., McCave, I. N., McManus, J. F., Mulitza, S., Ninnemann, U., Peeters, F., Yu, E. F., and Zahn, R.: Atlantic meridional overturning circulation during the last glacial maximum, Science, 316, 66-69, 2007.

Mackensen, A., Hubberton, H. W., Bickert, T., Fischer, G., and Futterer, D. K.: The $\delta^{13} \mathrm{C}$ in benthic foraminiferal tests of Fontbotia wuellerstorfi (Schwager) relative to the $\delta^{13} \mathrm{C}$ of dissolved inorganic carbon in Southern Ocean deep water: implications for glacial ocean circulation models, Paleoceanography, 8, 587-610, 1993.

Mackensen, A., Rudolph, M., and Kuhn, G.: Late Pleistocene deepwater circulation in the subantarctic eastern Atlantic, Global Planet. Change, 30, 197-229, 2001.

Marchitto, T. M., Curry, W. B., and Oppo, D. W.: Millennial-scale changes in North Atlantic circulation since the last glaciation, Nature, 393, 557-561, 1998.

Marinov, I., Gnanadesikan, A., Toggweiler, J. R., and Sarmiento, J. L.: The Southern Ocean biogeochemical divide, Nature, 441, 964-967, 2006.

Martinez-Mendez, G., Zahn, R., Hall, I. R., Pena, L. D., and Cacho, I.: 345000 year long multi-proxy records off South Africa document variable contributions of Northern versus Southern component water to the deep South Atlantic, Earth Planet. Sc. Lett., 267, 309-321, 2008.

Martrat, B., Grimalt, J. O., Shackleton, N. J., de Abreu, L., Hutterli, M. A., and Stocker, T. F.: Four climate cycles of recurring deep and surface water destabilizations on the Iberian margin, Science, 317, 502-507, 2007.

McCartney, M. S.: Subantarctic mode water, in: A voyage of Discovery, edited by: Angel, M. V., George Deacon 70th Anniversary Volume, Deep Sea Res., Suppl., 24, 103-119, 1977.

McManus, J. F., Oppo, D. W., and Cullen, J. L.: A 0.5-millionyear record of millennial-scale climate variability in the North Atlantic, Science, 283, 971-974, 1999.

McManus, J. F., Oppo, D. W., Cullen, J., and Healey, S.: Marine Isotope Stage 11 (MIS-11): Analog for Holocene and future climate? in: Earth's climate and orbital eccentricity: the marine isotope stage 11 question, edited by: Droxler, A. W., Poore, R. Z., and Buckle, L. H., AGU Geophysical Monograph, 137, 6985, 2003.

Mix, A. C., Le, J., and Shackleton, N. J.: Benthic foraminiferal stable isotope stratigraphy of Site 846: 0-1.8 Ma, Proceedings of the Ocean Drilling Program Scientific Results, 138, 839-854.

Mortyn, P. G., Charles, C. D., Ninnemann, U. S., Ludwig, K., and Hodell, D. A.: Deep sea sedimentary analogues for the Vostok ice core, Geochem. Geophy. Geosy., 4, 8405, doi:10.1029/2002GC000475, 2003. 
Muller, P. J. and Fischer, G.: $\mathrm{C}_{37}$-alkenones as paleotemperature tool: fundamentals based on sediment traps and surface sediments from the South Atlantic Ocean, in: The South Atlantic in the Late Quaternary: Reconstruction of material budgets and current systems, edited by: Wefer, G., Mulitza, S., and Ratmeyer, V., Spring-Verlag, Berlin, 167-193, 2003.

Ninnemann, U. S. and Charles, C. D.: Changes in the mode of Southern Ocean circulation over the last glacial cycle revealed by foraminiferal stable isotope variability, Earth Planet. Sc. Lett., 201, 383-396, 2002.

Oppo, D. W. and Fairbanks, R. G.: Variability in the deep and intermediate water circulation of the Atlantic Ocean during the past 25000 years: Northern Hemisphere modulation of the Southern ocean, Earth Planet. Sc. Lett., 86, 1-15, 1987.

Oppo, D. W., Fairbanks, R. G., and Gordon, A. L.: Late Pleistocene Southern Ocean $\delta^{13} \mathrm{C}$ variability, Paleoceanography, 5, 43-54, 1990.

Oppo, D. W. and Horowitz, M.: Glacial deep water geometry: South Atlantic benthic foraminiferal $\mathrm{Cd} / \mathrm{Ca}$ and $\delta^{13} \mathrm{C}$ evidence, Paleoceanography, 15, 147-160, 2000.

Oppo, D. W. and Lehman, S. J.: Mid-depth circulation of the subpolar North Atlantic during the Last Glacial Maximum, Science, 259, 1148-1152, 1993.

Oppo, D. W., McManus, J. F., and Cullen, J. L.: Abrupt climate events 500000 to 340000 years ago: evidence from subpolar North Atlantic sediments, Science, 279, 1335-1338, 1998.

Peacock, S., Lane, E., and Restrepo, J. M.: A possible sequence of events for the generalized glacial-interglacial cycle, Global Biogeochem. Cy., 20, GB2010, doi:10.1029/2005GB002448, 2006.

Petit, J. R., Jouzel, J., Raynaud, D., Barkov, N. I., Barnola, J-M., Basile, I., Bender, M., Chappellaz, J., Davis, M., Delaygue, G., Delmotte, M., Kotlyakov, V. M., Legrand, M. Lipenkov, V. Y., Lorius, C., Pepin, L., Ritz, C., Saltzman, E., and Stievenard, M.: Climate and atmospheric history of the past 420000 years from the Vostok ice core, Antarctica, Nature, 399, 429-436, 1999.

Pierre, C. Saliege, J. F. Urrutiaguer, M. J., and Giradeau, J.: Stable isotope record of the last $500 \mathrm{k} . \mathrm{y}$. at site 1087 (Southern Cape Basin), in: Proceedings of the Ocean Drilling Program, edited by: Wefer, G., Berger, W. H., and Richter, C., Scientific Results, 175, 1-22, 2001.

Poli, M. S., Thunell, R. C., and Rio, D.: Millennial-scale changes in North Atlantic Deep Water circulation during marine isotope stages 11 and 12: linkage to Antarctic climate, Geology, 28, 807$810,2000$.

Raymo, M. E., Ruddiman, W. F., Shackleton, N. J., and Oppo, D. W.: Evolution of Atlantic-Pacific $\delta^{13} \mathrm{C}$ gradients over the last 2.5 m.y, Earth Planet. Sc. Lett., 97, 353-368, 1990.

Romero, O., Boeckel, B., Donner, B., Lavik., G., Fischer, G., and Wefer, G.: Seasonal productivity dynamics in the pelagic central Benguela system inferred from the flux of carbonate and silicate organisms, J. Marine Syst., 37, 259-278, 2002.

Ruddiman, W. F. and McIntyre, A.: Ice age thermal response and climatic role of the surface Atlantic Ocean $40^{\circ} \mathrm{N}$ to $63^{\circ} \mathrm{N}$, Geol. Soc. Am. Bull., 95, 381-396, 1984.
Ruddiman, W. F.: Cold climate during the closest Stage 11 analog to recent Millennia, Quaternary Sci. Rev., 24, 111-1121, 2005.

Saunders, P. M. and King, B. A.: Oceanic fluxes on the WOCE A11 section, J. Phys. Oceanogr., 25, 1942-1958, 1994.

Schlitzer, R.: Ocean Data View, available at: http://odv.awi.de, 2006.

Shackleton, N. J., Imbrie, J., and Hall, M. A.: Oxygen and carbon isotope record of east Pacific core V19-30: implications for the formation of deep water in the late Pleistocene North Atlantic, Earth Planet. Sc. Lett., 65, 233-244, 1983.

Siegenthaler, U., Stocker, T. F., Monin, E., Luthi, D., Schwander, J., Stauffer, B., Raynaud, D., Barnola, J-M., Fischer, H., MassonDelmotte, V., and Jouzel, J.: Stable carbon cycle-climate relationship during the late Pleistocene, Science, 310, 1313-1317, 2005.

Siedler, G., Muller, T. J., Onken, R., Arhan, M., Mercier, H., King, B. A., and Saunders, P. M.: The zonal WOCE sections in the South Atlantic, in: The South Atlantic: past and present circulation, edited by: Wefer, G., Berger, W. H., Siedler, G., and Webb, D. J., Springer-Verlag, Berlin, 83-104, 1996.

Sigman, D. M. and Boyle, E. A.: Glacial/interglacial variations in atmospheric carbon dioxide, Nature, 407, 859-869, 2000.

Sigman, D. M. and Haug, G. H.: The biological pump in the past, in: Treatise in Geochemistry, edited by: Holland, H. D. and Turekian, K. K., Elsevier, 6, 539-549, 2003.

Stephens, B. B. and Keeling, R. F.: The influence of Antarctic sea ice on glacial-interglacial $\mathrm{CO}_{2}$ variations, Nature, 404, 171-174, 2000.

Thunell, R. C., Poli, M-S., and Rio, D.: Changes in deep and intermediate water properties in the western North Atlantic during marine isotope stages 11-12: evidence from ODP Leg 172, Mar. Geol., 189, 63-77, 2002.

Toggweiler, J. R.: Variation of atmospheric $\mathrm{CO}_{2}$ by ventilation of the ocean's deepest water, Paleoceanography, 14, 571-588, 1999.

Van Aken, H. M.: The hydrography of the mid-latitude Northeast Atlantic Ocean. Part I: The deep water masses, Deep-Sea Res., 47(5), 757-788, 2000.

Whitworth III, T. and Nowlin Jr, W. D.: Water masses and currents of the Southern Ocean at the Greenwich Meridian, J. Geophys. Res., 92(C6), 6462-6476, 1987.

Yu, E. F., Francois, R., and Bacon, M. P.: Similar rates of modern and last-glacial ocean thermohaline circulation inferred from radiochemical data, Nature, 379, 689-694, 1996.

Zahn, R., Winn, K., and Sarnthein, M.: Benthic foraminiferal $\delta^{13} \mathrm{C}$ and accumulation rates of organic carbon: Uvigerina peregrine group and Cibicidoides wuellerstorfi, Paleoceanography, 1, 2742, 1986.

Zeigler, K. E., Schwartz, J. P., Droxler, A. W., Shearer, M. C., and Peterson, L.: Caribbean carbonate crash in Pedro Channel at subthermoclinal depth during marine isotope stage 11: a case of basin to shelf carbonate fractionation? in: Earth's climate and orbital eccentricity: the marine isotope stage 11 question, edited by: Droxler, A. W., Poore, R. Z., and Buckle, L. H., AGU Geophysical Monograph, 137, 181-204, 2003. 